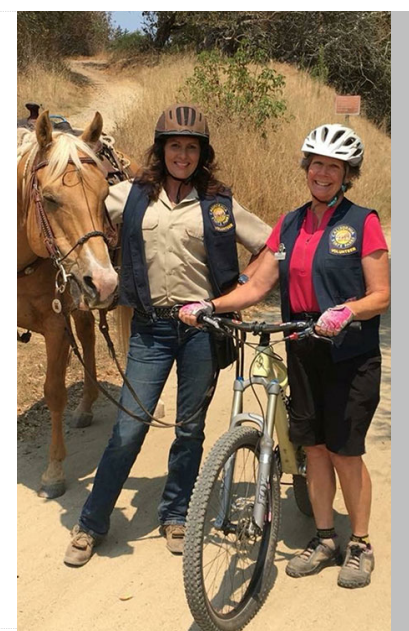

\title{
EVALUATING THE IMPACT OF VOLUNTEERS SERVING PUBLIC LANDS
}

\author{
Jeremy Lin* and Alison A. Ormsby \\ * Corresponding author: jeremy.lin@parks.ca.gov \\ Prescott College, Environmental Studies, Prescott, Arizona, USA
}

\section{ABSTRACT}

Volunteers fulfil an important role in operating and maintaining public lands and are therefore vital for the healthy function of California State Parks. Due to budgetary restrictions and increased park acreage, volunteers assume roles that have traditionally been held by ranger staff. Many studies focus on volunteer service in the fields of hospital care, social work and municipal administration, yet few have investigated the impact of volunteers serving public lands. To better understand this workforce, we conducted a cross-sectional study using surveys of 176 volunteers and 19 volunteer coordinators for California State Parks within the Santa Cruz District from August to October 2019. Survey questions focused on volunteer efforts in resource conservation, visitor services and daily park operations. Our findings show that volunteers accomplish agency objectives by facilitating interpretive programmes, providing visitor services and performing trail maintenance. In our analysis, three management implications emerged, revealing characteristics of sustainable volunteer programmes: 1) multiple volunteer coordinators per park unit reduces volunteer attrition; 2) recruiting volunteers based on pertinent professional skills maximises volunteer productivity; and 3) reducing volunteer coordinators attrition preserves institutional knowledge and long-term volunteers. By implementing these strategies, public lands agencies cultivate resilient volunteer programmes capable of fulfilling park and staff needs.

Key words: capacity building, management, recruitment, stewardship, state parks, training, volunteer coordination

\section{INTRODUCTION}

As volunteer responsibilities in parks expand in breadth and scope, it is important to understand the complex dynamic between volunteers, volunteer coordinators (VCs) and the public lands they serve (Cowan, 2012; CSP Statistical Report, 2018; VIPP Report, 2019). Volunteer programmes and partnerships are important for long-term public lands management, especially with recent budget cuts. Volunteers are generally considered to be a beneficial, and even critical part of the public land workforce (Handy \& Mook, 2011; Daniels et al., 2014). However, the extent to which volunteers achieve the mission objectives of the agencies they serve remains unclear.

A pattern of budgetary deficits within the public sector has increased reliance on volunteers to advocate for and protect publicly managed natural and cultural resources (Follman, 2015). Increased park visitation and acreage, and the inability of government to adequately fund parkland public services has promoted alliances and partnerships between the public, non-profit and private sectors (Googins \& Rochlin, 2000). As a result, neoliberal management strategies in the public lands sector continue to promote volunteer-dependent organisational structures to compensate for gaps in government staffing (Castree, 2008; Larner, 2003).

It is increasingly important to understand the social, environmental and economic impacts of volunteer efforts. Studies have shown that volunteer programmes have a profound and measurable impact on the healthy function of parks (Daniels et al., 2014; Follman, 2015). The number of California State Parks (CSP) volunteers have been increasing statewide, and provided over 159, ooo hours of visitor services, 126,000 hours of trail maintenance and 77,00o hours of natural and cultural resource management in 2017 (VIPP Report, 2019). Studies have found evidence that volunteer programmes foster positive social outcomes such as training a highly skilled and marketable workforce (Classens, 2015; Elias et al., 2016), improved mental and physical health of volunteers (Cnaan \& Goldberg-Glen, 1991; Manetti et al., 2015), and increased civic engagement and participation (Ryan et al., 2001; Homana, 2018). Environmental impacts from volunteer programmes 
include successful habitat restoration work (Ryan \& Grese, 2005; Ganzevoort et al., 2017), contribution to citizen science data collection to influence park management decisions (Ryan et al., 2001; Jordan et al., 2012 Andow et al., 2016), and environmental policy and lobbying efforts (Walton, 2015). Economic impacts from volunteer programmes include offsetting and/or supplementing operational costs of public agencies (Jordan et al., 2012; Manetti et al., 2015), generating profit by providing pay services (Follman, 2015), and fundraising for park programmes and infrastructure improvement projects (Reidy et al., 2005).

Volunteers are a ubiquitous and productive workforce throughout CSP, therefore it is important to understand volunteer roles and responsibilities, characteristics of successful volunteer programmes, and the ability of volunteers to accomplish agency objectives. We examined the benefits and challenges of volunteer programmes serving CSP, identified the patterns and consequences of $\mathrm{VC}$ and volunteer attrition, optimal ratios of volunteers to $\mathrm{VC}$, and volunteer recruitment and training standards to improve volunteer programmes and inform long-range park management planning.

Although volunteer work is an important component of the park system, volunteer coordination is often a peripheral responsibility, and commonly listed as 25 per cent of total work time (Interpreter Qualifications, 2019). VCs have many other professional responsibilities outside of volunteer coordination, including leading interpretive programmes, administrative duties (e.g. budgetary, long range planning), and social media management.

Our study focused on all CSP within Santa Cruz District, which includes over 80,000 acres of diverse landscape within 30 individual park units (CSP Statistical Report, 2018). Santa Cruz District is a fitting representation of the statewide park system because of its diverse natural and cultural resources, recreational opportunities, and proximity to urbanised population centres and remote backcountry areas.

CSP is made up of 280 individual park units, 340 miles of coastline, 970 miles of river and lake frontage, 15,000 campsites and 4,500 miles of trails, with over 70 million annual visitors (CSP Statistical Report, 2018). Managing the ecological health and functional operation of widespread, abundant and diverse park units requires a cadre of diligent and consistent volunteers to support the paid park staff. For example, Rancho del Oso - Big Basin Redwoods State Park, a single 1,800-acre park unit along the northern coast of

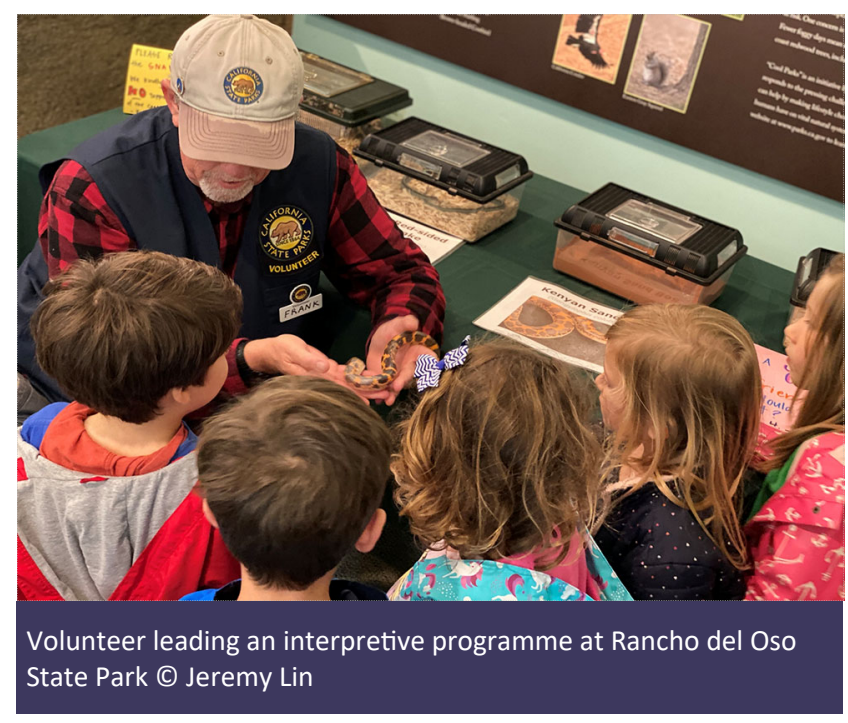

Santa Cruz, enlists the service of 35 volunteers to support the park interpreter, rangers and maintenance crew (VIPP Report, 2019). In 2017, CSP employed just over 1,600 permanent staff and managed over 36,000 volunteers statewide, averaging 22 volunteers for each permanent CSP staff member (CSP Statistical Report, 2018; VIPP Report, 2019).

In 2017, VCs spent 115,000 work-time hours to facilitate more than 36,000 volunteers to contribute over 1.1 million hours of work within the CSP (VIPP Report, 2019). It is difficult to determine the return on investment (ROI) for volunteer programmes, in part due to differences in agency objectives and inconsistent evaluation models. The uncertainty of volunteer value may be attributed to inaccurate and/or incomplete valuation models used to analyse volunteer efforts (Hackl et al., 2007; Sajardo \& Serra, 2011). Few studies have investigated the roles, responsibilities, attitudes and behaviours of volunteers that serve public lands; this is why we chose to explore this topic.

\section{METHODS}

Our research focused on the following questions:

1. What are the benefits and challenges associated with volunteer programmes serving CSP?

2. What are the characteristics of highly effective volunteer programmes?

3. Are volunteers being adequately trained?

Online electronic questionnaire surveys were emailed to Santa Cruz State Parks VCs $(\mathrm{n}=19)$ and volunteers $(n=761)$ in August 2019 using Google Forms, and were returned by October 2019. In two similar studies, researchers sampled a volunteer population with approximately 200 volunteers (Reidy et al., 2005; Ryan \& Grese, 2005). Surveys were emailed to VCs and 
volunteers following similar methods used by Dresner (2012). A total of 176 volunteers (out of 761) and all 19 VCs responded to the survey.

We developed two questionnaires-one for paid VCs and another for volunteers-designed to collect demographic data, volunteer and professional work experience, responsibilities and objectives within CSP, and attitudes and confidence in the current volunteer management system (see Supplementary Online Material). Surveys for both VCs and volunteers included demographic questions and structured response questions using a 5-point Likert scale, which were modelled after questions in Dresner (2012), and openended questions, modelled after Manetti et al. (2015) and Ryan and Grese (2005). VC attitude questions focused on perceived relevance and effectiveness of the volunteer management system, professional responsibilities and interactions with volunteers. Behavioural questions related to involvement in volunteer recruitment, retention and management. The volunteer survey included attitude questions relating to daily volunteer duties, interactions with VCs and other CSP staff, motivation for volunteering, and obstacles in their service. Behaviour questions investigated volunteer activities, locations and accomplishments.

We conducted comparative analyses of volunteer management practices, representative summary statistics, and an assessment of the real-world implications of volunteer management strategies. We used RStudio statistical analysis software to conduct comparative and correlative tests. We also rated and grouped the qualitative responses from each of the surveys into categories. For example, we classified responses from the following volunteer survey question: "What are the biggest challenges you experience when volunteering for CSP?" into a category list including "park understaffing", "scheduling availability" and "technology".

\section{RESULTS}

\section{Volunteer survey}

The volunteer survey reached a 23 per cent response rate $(n=176)$ with 109 female and 59 male participants. Volunteers surveyed were 55-74 years old with 79 per cent of participants achieving an education level of bachelor's or advanced degrees. Professional experience among volunteers ranged broadly, with current and previous occupations including firefighter, astrophysicist, software engineer, lawyer and medical worker. (For full details on the complete study, see Lin, 2020.)
When asked, "On average, how many hours per month do you spend volunteering with CSP?", 39 per cent of volunteers reported working over 10 hours each month. Relating to volunteer effectiveness, longer volunteer tenure was significantly correlated with parks that employ more than one volunteer coordinator (Pearson's $\mathrm{r}=0.546, \mathrm{p}=1.84 \mathrm{e}-11, \mathrm{n}=174)$, revealing that volunteers stay longer when they are supported by more than one VC. Although 60 per cent of volunteers had over 30 hours of training, many participants wanted additional training on specific subjects including leading interpretive tours, natural history and biodiversity, and using technology. The most common volunteer objectives were roving interpretation, leading scheduled interpretive tours, and providing public safety services (Figure 1). Many respondents listed several volunteer objectives.

Also related to volunteer effectiveness, in response to the question, "Which of your professional skills are most useful in accomplishing these objectives?", 54 per cent of survey participants asserted that "communication" is the most useful skill (Figure 2).

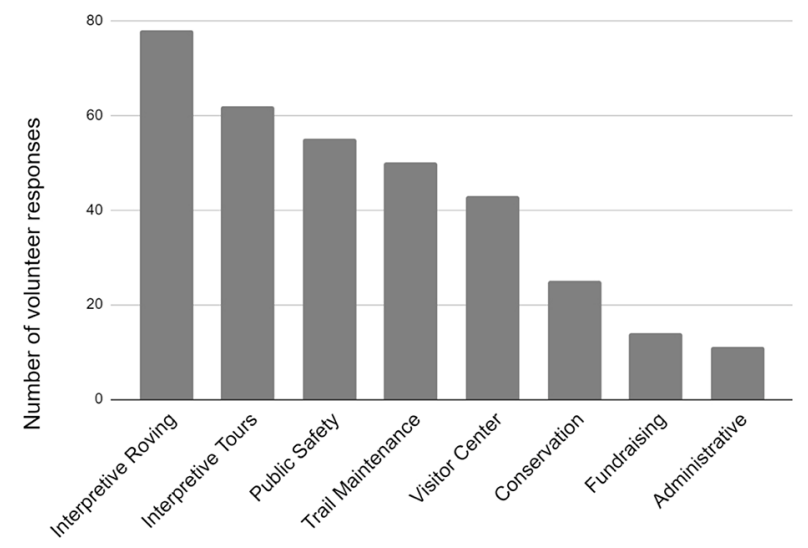

Figure 1. Volunteer objectives

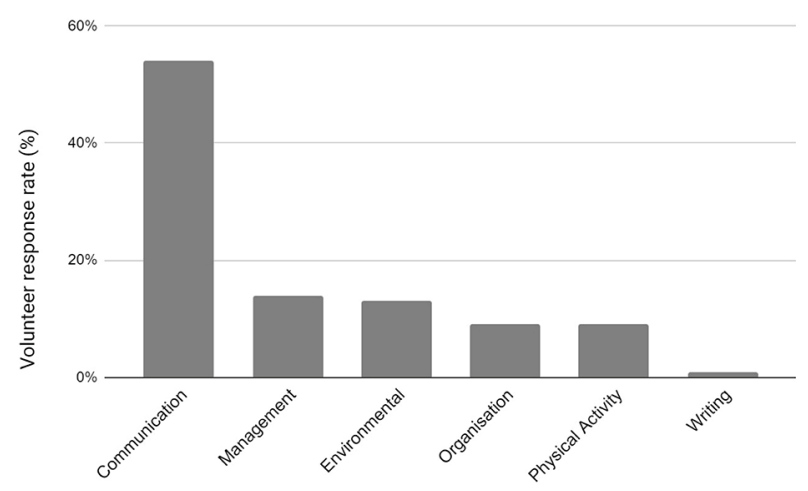

Figure 2. Volunteers' most commonly used professional skills 
To answer the research question about benefits from volunteering, when asked about the positive impacts of their volunteer service on parks and visitors, volunteers believed that they contribute most by connecting visitors to nature through interpretive programmes, engaging in stewardship activities, and providing public safety services (Figure 3). Many respondents listed several positive impacts of their work, including stories of meaningful and altruistic interactions, such as: "helping visitors feel the park", "sharing my love for the natural world around me in the hopes that park visitors will also realize the same love themselves", and demonstrating an "open hearted commitment toward public safety".

When asked about the most rewarding aspects and benefits of their service, volunteers were proud to share ideals of environmental stewardship with the public including "to help people, help protect natural resources and occasionally have personal moments of wonder", "feelings of accomplishment, service, gratitude", and "feeling a sense of wholeness that comes from giving back to the parks". Overall, volunteers expressed a great sense of pride in their responsibility to, as one volunteer said, "awaken an understanding and appreciation for the wonders of the natural world", while engaging with park visitors. Volunteers conveyed great joy in their work and feel rewarded by the physical challenge, helping researchers, and purposeful service to public lands. Volunteers appeared to be motivated to engage in meaningful human connections, experience the natural world, and be part of a mission-driven community.

\section{Volunteer Coordinator survey}

The VC survey received a 100 per cent response rate $(n=19)$ with 12 female and 7 male participants. The modal age of VCs was 18-24 years old with 79 per cent of participants achieving an education level of Bachelor's or advanced degrees. Professional experience

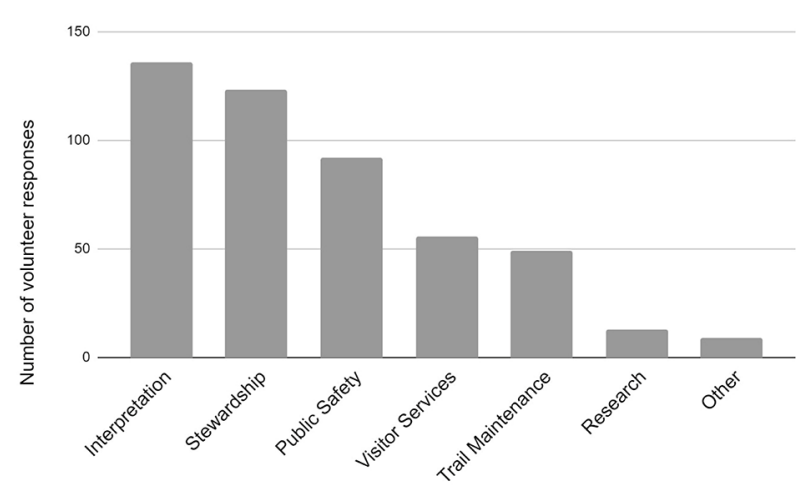

Figure 3. Areas where volunteers feel they make the most positive impact among respondents was fewer than five years of experience as a VC (63 per cent, Figure 4).

Regarding both volunteer training and challenges, the majority of VCs have undergone formal training through CSP yet continue to face challenges. When asked "What are your main challenges in coordinating volunteers?", respondents asserted that they do not have enough time to adequately coordinate their park's many volunteers, struggle with recruiting diverse and fitting volunteers, and would benefit from technology (i.e. database software) to track volunteer information, scheduling and hours.

Our research found that VCs aim to inspire a strong stewardship ethic among volunteers and provide general guidance, support and maintain standards of high quality for interpretive programmes. VCs also see their role as community builders, park managers and frontline representatives of their park.

VCs believe that volunteers are motivated primarily by their personal connection with the parks, the connections that they make with park visitors, and their interest in learning about the natural environment. Respondents mentioned that many of their volunteers have professional experience as educators. The primary responsibilities of volunteers are leading interpretive programmes for public audiences, school groups and other special interest groups (e.g. researchers, environmental groups). Other volunteer duties include public safety service (e.g. patrolling, rules and regulations, medical response), trail maintenance, and natural and cultural resources protection (i.e. habitat restoration).

Sixty-three per cent of VCs surveyed believed that volunteers are very and/or extremely effective in accomplishing their responsibilities and objectives. (Figure 5).

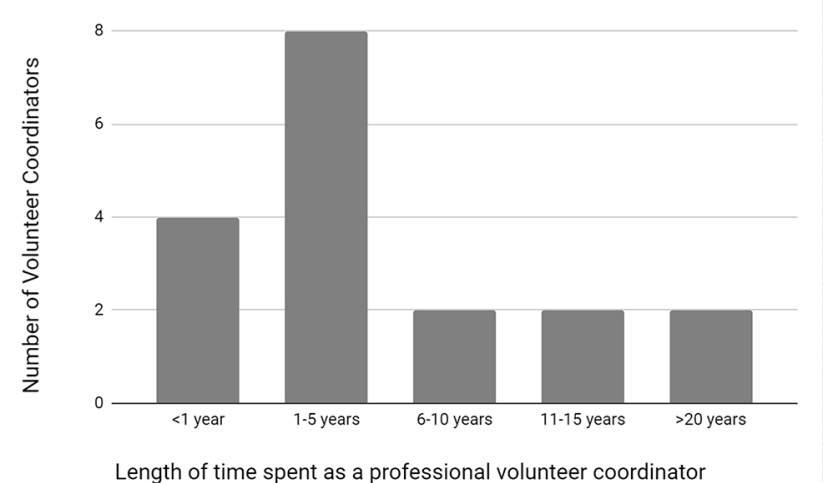

Figure 4. Extent of volunteer coordination experience in years 


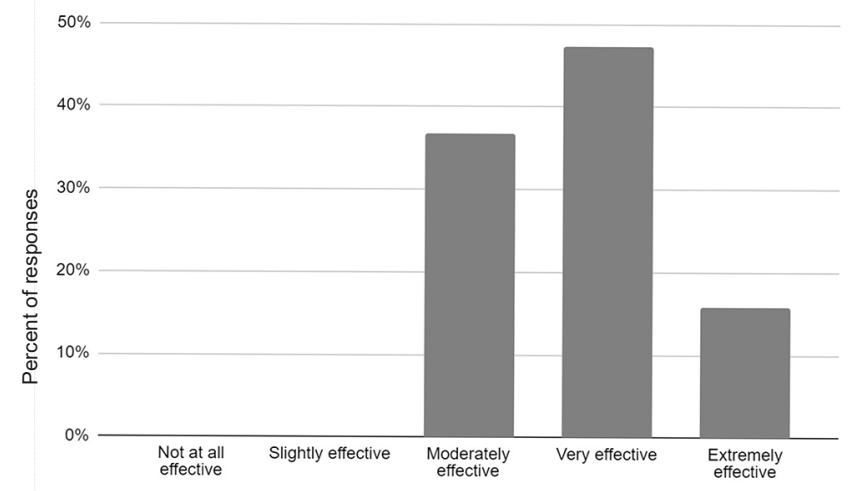

Figure 5. Volunteer Coordinators' confidence in volunteers accomplishing objectives

Many respondents described their volunteer programmes enthusiastically and positively; for example, one $\mathrm{VC}$ insisted "Our volunteers are wonderful and committed people who really make the goals of State Parks possible." When asked, "How effective are volunteers in accomplishing their responsibilities and objectives? Explain", VCs often stated that their volunteers' prior and relevant experience and knowledge are the most important factors in supporting their parks' objectives. Other important factors include public speaking, punctuality and personal interest in the park. When asked "Are volunteers being adequately trained/prepared to uphold the standards of California State Parks?”, VCs expressed belief that volunteers are well and/or extremely well trained to uphold CSP standards.

When asked to explain how volunteer training could be improved, respondents suggested that offering specialised and/or advanced training (e.g. group management skills, trail tools, technology) may be useful. VCs expressed a need for improved volunteer recruitment strategies, suggesting that park units experience high rates of volunteer attrition and they struggle to fulfil the recurring need for skilled park volunteers.

VCs manage varying numbers of volunteers depending on the scope and size of each park unit, with the most frequent number of volunteers per $\mathrm{VC}$ being in the category of between 26-50 volunteers. VCs believed that the optimal number of volunteers under their coordination is between 10-25 volunteers. In addition, VCs spend less than 20 per cent of their work time training volunteers, yet over 30 per cent of work time is spent on coordinating volunteers.

Overall, VCs convey their pride in working with volunteers and express confidence that volunteers are providing a service to the park and community. As one

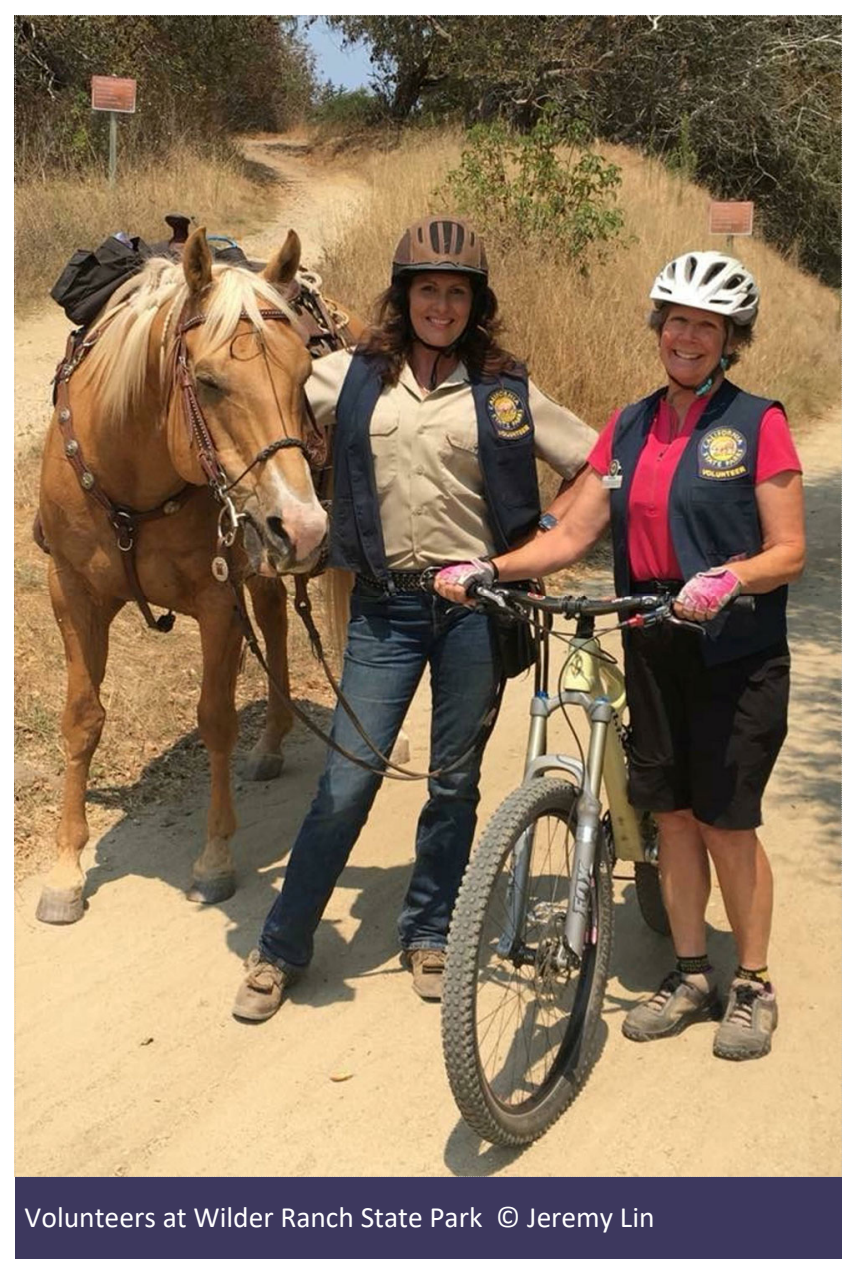

VC wrote, "Volunteer management is a challenge and a joy...[volunteers] fiercely defend the park, and serve as an inner circle of knowledgeable and caring folks whose reach ripples outward through the whole community." Another VC, with over 5 years of experience articulated that "State Parks would NOT run this successfully without volunteers."

\section{DISCUSSION}

\section{Volunteer perspectives}

Volunteers bring an array of professional skills to their service including backgrounds in natural science, wilderness medicine and trail work, as observed in other studies (Steimel, 2018; Ganzevoort et al., 2017). In our study, communication was seen as the most practical professional skill brought to volunteer service from the perspectives of both VCs and volunteers.

When asked about obstacles and challenges in service to parks, the issue of park understaffing was frequently mentioned by volunteers, indicating that even if a volunteer base is well qualified and highly skilled, the volunteer programme may be lacking due to inadequate staff numbers. High VC attrition rates contribute to 
understaffing because volunteers are often left without a direct line of communication or link to the park system for the extended periods of time it takes to fill vacancies and train new staff. These findings are congruent with a study conducted by Hackl et al. (2007) noting that volunteers are ineffective without clear duty statements and responsibilities.

CSP struggles to recruit and maintain young volunteers, with the majority of volunteers 65 years or older. The trend of older volunteers has been recognised in volunteer demographic studies (Wilson et al., 2017; Elias et al., 2016). This is concerning because the park system relies on an aging population for physically strenuous outdoor tasks including trail work and leading hikes. Parks will benefit from targeting and recruiting younger volunteers.

Our study found that volunteers are adequately trained and prepared to uphold CSP standards. However, additional volunteer training opportunities are necessary to optimise volunteers' ability to accomplish specific park objectives. Many VCs are unable to implement specialised training opportunities due to time constraints. This has consequences for the volunteer workforce, causing volunteers to be less effective in performing specialised tasks. Similar to findings of Liao-Troth (2008), volunteer programmes fail to accomplish agency goals when volunteers are uncertain about their roles and unclear about their specific responsibilities. VCs may consider recording and offering online training seminars, which are less time intensive and may provide volunteers with key knowledge and tools.

\section{VOLUNTEER COORDINATOR REFLECTIONS}

Most VCs had fewer than five years of experience in their field, indicating a high rate of attrition. For example, at Wilder Ranch State Park, one VC position has seen four new VCs over the course of three years. This finding underscores the difficulty in maintaining experienced park staff. VC roles are specialised; therefore, frequent staff turnover is detrimental to the park system (Andow et al., 2016; Bembry, 1996). Our study found that VCs are overwhelmed by the large number of volunteers under their coordination and do not have enough time to adequately recruit, train and coordinate their volunteers. Many VCs are only permitted to work part-time, requiring employees to work a second job. Therefore, VCs suggested that professional incentives (e.g. pay increases, full-time positions) would increase their longevity in the profession and improve the volunteer programme, similar to findings of Bembry (1996) in Maryland. Due to the high cost of training VCs, future research should focus on how to address the needs of VCs to improve retention.

VC attrition may also cause problems in recruiting and managing volunteers, as also observed by Hager and Brudney (2011). In this study, researchers found that VCs for public charities across the United States experience higher success in volunteer productivity and retention when they have undergone volunteer management training. In our study, we were surprised that many VCs were unaware of standard tools and technology that are specifically designed to support their work. Interestingly, a quarter of VCs expressed the urgent need for technologies that are not only available, but mandated for use by the park system. This highlights the need for frequent VC training covering technological resources, especially when mitigating high $\mathrm{VC}$ turnover rates.

VCs asserted that the optimal number of volunteers under their coordination is $10-25$, whereas the actual most common number of volunteers under their coordination is 26-50. VCs struggle to manage large groups of volunteers, with 34 per cent of their total work time dedicated to volunteer recruitment, training and coordination, even though volunteer management is often listed as 25 per cent of total work-time responsibilities (Interpreter Qualifications, 2019). The hiring and incorporation of additional VC positions will not only relieve the overburdened staff, it will allow VCs to manage volunteers and attend to their other professional responsibilities.

We found that VCs believed that a volunteer's prior experience and knowledge are the most important factors in achieving park objectives, reinforcing the findings of Steimel (2018). In this study, researchers evaluated the effectiveness of skills-based volunteering in various professions including dental hygienists, assistant teachers and athletic trainers. Researchers found that skills-based volunteer recruitment enhances the non-profit organisation that they serve.

Similar to findings of Nesbit et al. (2018) and Waikayi et al. (2012), VCs in our study believed that volunteers are well-trained and equipped to perform tasks, however volunteers' success is affected by their prior professional skills and experience. For instance, the public speaking experience of a retired schoolteacher is valuable preparation for leading nature walks with visiting school groups. Also, a volunteer who formerly worked as a hydrologist brings valuable insight and knowledge to restore impaired riparian habitat. Targeted volunteer recruitment to match expertise with park needs is advantageous in maximising agency resources. 


\section{What are the benefits and challenges associated with volunteer programmes?}

Each park has unique volunteer needs depending on location, natural and cultural resources, and visitor recreation opportunities. Volunteer programmes are equally as diverse and therefore each volunteer programme is specifically designed to accommodate the site needs. Additional challenges include the heavy investment cost to staff VCs (Graff, 2006), frequently recruiting and training volunteers (Hager \& Brudney, 2011), and VC and volunteer attrition (Bembry, 1996; Liao-Troth, 2008). However, volunteer programmes provide many beneficial services including meeting public demand for interpretive programmes, restoring natural habitat, maintaining accessible trail systems, and increasing visitor services (Daniels et al., 2014).

In summary, through our survey and literature review research, we concluded that park units experiencing the most benefit from volunteer programmes are those that embody the following characteristics:

- More than one VC staff member dedicated to volunteer recruitment, training and retention (Manetti et al., 2015; Wilson et al., 2017).

- $\mathrm{VC}(\mathrm{s})$ with multiple years of professional experience (Vinton, 2012; Studer \& von Schnurbein, 2013).

- One volunteer coordinator per 10-25 volunteers (depending on specific park needs).
- Volunteer recruitment strategies based on relevant professional skills and experience (Ellis, 2002; Brudney \& Meijs, 2014).

- Volunteer trainings offered regularly, focusing on general responsibilities and specialised skills (Reidy et al., 2005; Jordan et al., 2012).

- VC trainings offered regularly, focusing on tools, technology and volunteer coordination strategies.

\section{Management implications}

VCs and volunteers are essential contributors in a variety of ways, including enhancing interpretive programmes, providing visitor services, and maintaining trails and facilities. VCs and volunteers embody a strong personal passion and sense of duty for their service.

Volunteers are sufficiently trained and equipped to perform tasks outlined in their duty statements. However, there are many ways to improve the volunteer management system including employing more than one $\mathrm{VC}$ at each park unit, recruiting volunteers with relevant professional skills, and taking steps to reduce $\mathrm{VC}$ attrition. Three central themes emerged through our research, which directly address our initial research questions:

1. Employing more than one VC per park unit and maintaining a low ratio of volunteers per $\mathrm{VC}$ will reduce volunteer attrition and provide the volunteer

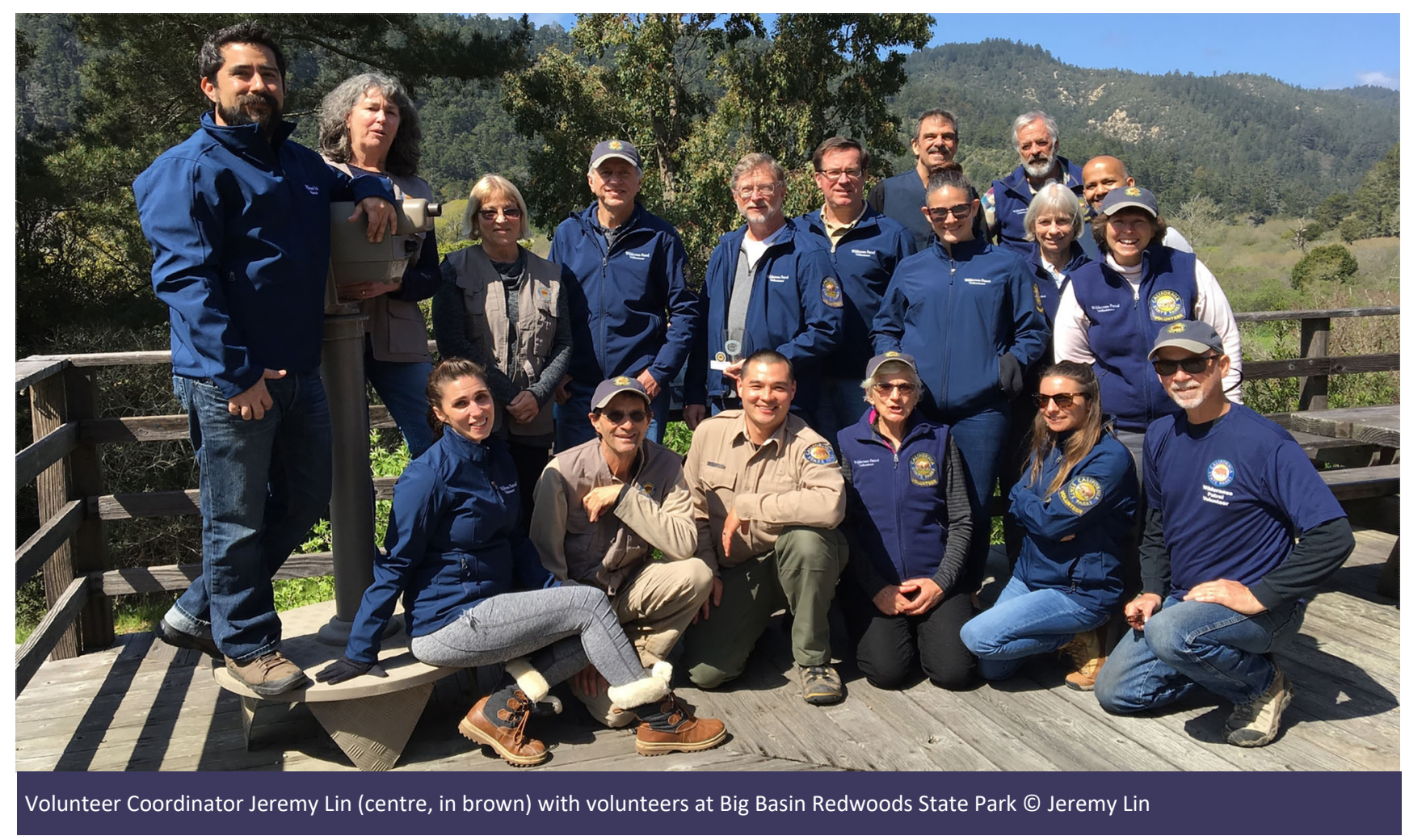


support needed to accomplish park-specific goals and objectives.

2. Targeting and recruiting volunteers based on pertinent professional skills and experience will maximise volunteer productivity and reduce impact on agency resources.

3. Maintaining experienced, long-term $\mathrm{VCs}$ and reducing staff attrition will benefit the park system by protecting institutional knowledge and achieving long-range park management priorities.

We noticed that parks that employ multiple VCs enjoy a higher level of productivity, volunteer morale, and ability to diversify volunteer roles and responsibilities. It is evident that long-term, experienced VCs take advantage of departmental resources and tools, and are respected as leaders among their volunteer base. We also noted that volunteers who join the park system with relevant professional skills can be extremely productive and require less $\mathrm{VC}$ attention and training time.

Volunteer programmes represent the community's support and inclusion in the core park mission by protecting extraordinary natural resources and connecting people to meaningful park experiences. In order to secure the future of public lands, it is imperative to acknowledge the extent to which volunteers contribute to parks. Furthermore, public lands agencies that incorporate volunteer tourism as a fundamental management strategy benefit from public involvement in park enhancement activities (Weaver, 2015).

CSP has great potential to benefit from the purposeful management of volunteers through the understanding of volunteer roles and incorporating volunteer programmes into long-range initiatives and planning. Investing in volunteer programmes will result in healthier ecosystems, thriving communities and a more resilient park system. We believe that our study methods and recommendations can be applied beyond just the state of California.

\section{SUPPLEMENTARY ONLINE MATERIAL}

Questionnaires used in study

\section{ABOUT THE AUTHORS}

Jeremy Lin is an Interpreter II with California State Parks and has ten years of experience in the fields of parks management, interpretation, and conservation. $\mathrm{He}$ has worked for multiple public lands agencies including national parks, state parks, and regional parks systems. orcid.org/oooo-00o3-4588-5466
Alison Ormsby is a Graduate Mentor in Environmental Studies at Prescott College and has 30 years of experience working in parks globally, including in Sierra Leone, Madagascar, Ghana, India, and the United States. She is a member of the IUCN's Specialist Group for Cultural and Spiritual Values of Protected Areas. orcid.org/o0oo-0002-0662-6819

\section{REFERENCES}

Andow, D., Borgida, E., Hurley, T. and Williams, A. (2016). Recruitment and retention of volunteers in a citizen science network to detect invasive species on private lands. Environmental Management 58(4):606-618. https:// doi.org/10.1007/s00267-016-0746-7

Bembry, J.X. (1996). The impact of volunteer coordinators on volunteer programs: An evaluation of Volunteer Maryland! Volunteer Administration 14(2):14-20. Available at: https:// pubmed.ncbi.nlm.nih.gov/10156301/

Brudney, J. and Meijs, L. (2014). Models of volunteer management: Professional volunteer program management in social work, human service organizations. Management, Leadership \& Governance 38(3):297-309. https:// doi.org/10.1080/23303131.2014.899281

Castree, N. (2008). Neoliberalising nature: Processes, effects, and evaluations. Environment and Planning A: Economy and Space. 40(1):153-173. https://doi.org/10.1068/a39100

Classens, M. (2015). What's in it for the volunteers? An SROI approach to volunteers' return on investment in the good food markets. Nonprofit Management and Leadership 26(2):145156. https://doi.org/10.1002/nml.21189

Cnaan, R.A. and Goldberg-Glen, R.S. (1991). Measuring motivation to volunteer in human services. Journal of Applied Behavioral Science 27(3):269-284. https:// doi.org/10.1177/0021886391273003

Cowan, M. (2012). Volunteers in parks program guidelines. California State Parks Interpretation and Education Division. Available at: https://www.parks.ca.gov/pages/735/files/vipp\% 20guidelines\%20low\%20res\%2003-21-12.pdf.

California State Parks (CSP) Statistical Report (2018). Planning, recreation and support section marketing and business development office. Statistical Report 2015/2016. Available at: http://www.parks.ca.gov/pages/795/files/15-16\% 20Statistical\%20Report\%20FINAL\%20ONLINE.pdf.

Daniels, J.M., Robbins, A.S., Brinkley, W.R., Wolf, K.L. and Chase, J.M. (2014). Toward estimating the value of stewardship volunteers: A cost-based valuation approach in King County, Washington, USA. Urban Forestry \& Urban Greening 13 (2):285-289. https://doi.org/10.1016/j.ufug.2014.01.004

Dresner, M. (2012). Environmental identity, pro-environmental behaviors, and civic engagement of volunteer stewards in Portland area parks. Environmental Education Research 21 (6):991-1010. https://doi.org/10.1080/13504622.2014.964188

Elias, J.K., Sudhir, P. and Mehrotra, S. (2016). Long-term engagement in formal volunteering and well-being: An exploratory Indian study. Axioms 5(4):1-15. https:// doi.org/10.3390/bs6040020

Ellis, S.J. (2002). The volunteer recruitment (and membership development) book (3rd ed.). Philadelphia: Energize, Inc. 
Follman, J.M. (2015). Co-coordinated volunteer programs at U.S. National parks: A multi-case study of volunteer partnerships. Dissertation Abstracts International Section A, 76. Available at: https://pqdtopen.proquest.com/doc/1669973664.html? $\mathrm{FMT}=\mathrm{Al}$

Ganzevoort, W., Born, R., Halffman, W. and Turnhout, S. (2017). Sharing biodiversity data: citizen scientists' concerns and motivations. Biodiversity Conservation 26(12):2821-2837. https://doi.org/10.1007/s10531-017-1391-z

Googins, B. and Rochlin, S. (2000). Creating the partnership society: understanding the rhetoric and reality of crosssectoral partnerships. Business and Society Review 105 (1):127-144. https://doi.org/10.1111/0045-3609.00068

Graff, L. (2006). Declining profit margin: when volunteers cost more than they return. International Journal of Volunteer Administration 24(1):24-32. Available at: https:// www.ijova.org/docs/

IJOVA_VOL24_NO1_Profit_Margin_Linda_Graff.pdf

Hackl, F., Halla, M. and Pruckner, G.J. (2007). Volunteering and income: The fallacy of the Good Samaritan? Kyklos 60:77104. https://doi.org/10.1111/j.1467-6435.2007.00360.x

Hager, M.A. and Brudney, J.L. (2011). Problems recruiting volunteers: nature versus nurture. Nonprofit Management and Leadership 22(2):137-157. https://doi.org/10.1002/nml.20046

Handy, F. and Mook, L. (2011). Volunteering and volunteers: Benefit-cost analyses. Research on Social Work Practice 21 (4):412-420. https://doi.org/10.1177/1049731510386625

Homana, G.A (2018). Youth political engagement in Australia and the United States: Student councils and volunteer organizations as communities of practice. Journal of Social Science Education 17(1):41-54. https://doi.org/10.4119/ UNIBI/jsse-v17-i1-1674

Interpreter Qualifications (2019). State Park Interpreter I (2826). California State Personnel Board Specification. Available at: http://www.calhr.ca.gov/state-hr-professionals/ Pages/2826.aspx.

Jordan, R., Brooks, W., Howe, D. and Ehrenfeld, J. (2012). Evaluating the performance of volunteers in mapping invasive plants in public conservation lands. Environmental Management 49(2):425-434. https://doi.org/10.1007/s00267011-9789-y

Larner, W. (2003). Neoliberalism? Environment and Planning D: Society and Space. 21(5):509-512. https://doi:10.1068/ d2105ed

Liao-Troth, M. (Ed.) (2008). Introduction: challenges in volunteer management. In: Challenges in volunteer management ( $\mathrm{pp}$. ix -xii). Charlotte: IAP Information Age Publishing.

Lin, J.M. (2020). Evaluating the impact of volunteers serving public lands [Master's thesis, Prescott College]. https://bit.ly/3iNLjOI

Manetti, G., Bellucci, M., Como, E. and Bagnoli, L. (2015). Investing in volunteering: measuring social returns of volunteer recruitment, training and management. Voluntas: International Journal of Voluntary \& Nonprofit Organizations 26(5):2104-2129. https://doi.org/10.1007/s11266-014-9497-3

Nesbit, R., Christensen, R.K. and Brudney, J.L. (2018). The limits and possibilities of volunteering: a framework for explaining the scope of volunteer involvement in public and nonprofit organizations. Public Administration Review 78(4):502-513. https://doi.org/10.1111/puar.12894

Reidy, M., Chevalier, W. and McDonald, T. (2005). Lane Cove National Park bushcare volunteers: taking stock, 10 years on. Ecological Management and Restoration 6(2):94-104. https:// doi.org/10.1111/j.1442-8903.2005.00225.x

Ryan, R.L. and Grese, R.E. (2005). Urban volunteers and the environment: forest and prairie restoration. In P.F. Barlett (Ed.), Urban place: Reconnecting with the natural world, (pp. 173-188). Cambridge, MA, US: MIT Press.

Ryan, R.L., Kaplan, L. and Grese, R.E. (2001). Predicting volunteer commitment in environmental stewardship programmes. Journal of Environmental Planning and Management 44(5):629-648. https:/l doi.org/10.1080/09640560120079948

Sajardo, A. and Serra, I. (2011). The economic value of volunteer work: methodological analysis and application to Spain. Nonprofit and Volunteer Sector Quarterly 40(5):873-895. https://doi.org/10.1177/0899764010371233

Steimel, S. (2018). Skills-based volunteering as both work and not work: a tension-centered examination of constructions of "volunteer". Voluntas: International Journal of Voluntary \& Nonprofit Organizations 29(1):133-143. https:// doi.org/10.1007/s11266-017-9859-8

Studer, S. and von Schnurbein, G. (2013). Organizational factors affecting volunteers: A literature review on volunteer coordination. Voluntas 24:403-440. https://doi.org/10.1007/ s11266-012-9268-y

Vinton, L. (2012). Professional administration of volunteer programs now more than ever: A case example. Administration in Social Work 36(2):133-148. https:// doi.org/10.1080/03643107.2011.564721

VIPP Report (2019). Volunteers in parks program annual report. California State Parks Partnerships Office. Available at: https://www.parks.ca.gov/pages/735/ files/2018VIPP_Report_Final20190605.pdf.

Waikayi, L., Fearon, C., Morris, L. and McLaughlin, H. (2012). Volunteer management: An exploratory case study within the British Red Cross. Management Decision 50(3):349-367. https://doi.org/10.1108/00251741211216188

Walton, M. (2015). Community management of public land: keeping green assets viable. Ecosystems - A Review of Conservation 36(1):44-51. Available at: https:// www.ecos.org.uk/wp-content/uploads/2015/05/ECOS-36-1-44 -Community-management-of-public-land.pdf

Weaver, D. (2015). Volunteer tourism and beyond: motivations and barriers to participation in protected area enhancement. Journal of Sustainable Tourism 23(5):683-705. https://doi.org/10.1080/09669582.2014.992901

Wilson, M., Mirchandani, D. and Shenouda, R. (2017). Olderperson volunteering in rural and regional Australia: Recruitment, retention, and health benefits. Educational Gerontology 43(3):139-146. https:// doi.org/10.1080/03601277.2016.1269546 


\section{RESUMEN}

Los voluntarios desempeñan un papel importante en el funcionamiento y el mantenimiento de los terrenos públicos y, por tanto, son esenciales para el buen funcionamiento de los parques estatales de California (PEC). Debido a las restricciones presupuestarias y al aumento de la superficie de los parques, los voluntarios asumen funciones que tradicionalmente han sido desempeñadas por el personal de los guardaparques. Muchos estudios se centran en el servicio voluntario en el ámbito de la atención hospitalaria, el trabajo social y la administración municipal, pero pocos han investigado el impacto de los voluntarios que prestan servicio en las tierras públicas. Para comprender mejor esta fuerza laboral, de agosto a octubre de 2019 realizamos un estudio transversal utilizando encuestas de 176 voluntarios y 19 coordinadores de voluntarios (CV) para los PEC dentro del distrito de Santa Cruz. Las preguntas de la encuesta se centraron en los esfuerzos de los voluntarios en la conservación de los recursos, los servicios a los visitantes y las operaciones diarias de los parques. Los resultados obtenidos muestran que los voluntarios cumplen con los objetivos previstos, facilitando programas interpretativos, proporcionando servicios a los visitantes y realizando el mantenimiento de los senderos. En nuestro análisis, surgieron tres repercusiones en el terreno que revelan las características de los programas de voluntariado sostenibles: 1) La asignación de múltiples coordinadores de voluntarios por sector del parque reduce el desgaste de los voluntarios; 2) La contratación de voluntarios con base en las competencias profesionales pertinentes maximiza la productividad de los voluntarios; y 3) La reducción del desgaste de los coordinadores de voluntarios preserva el conocimiento institucional y los voluntarios de larga duración. Mediante la implementación de estas estrategias, los organismos responsables de las tierras públicas desarrollan programas de voluntariado resilientes capaces de satisfacer las necesidades de los parques y del personal.

\section{RÉSUMÉ}

Les bénévoles jouent un rôle important dans l'exploitation et l'entretien des terres publiques et sont donc vitaux pour le bon fonctionnement des California State Parks (CSP). En raison des restrictions budgétaires et de l'augmentation de la superficie du parc, les bénévoles doivent assumer des rôles qui étaient traditionnellement occupés par les gardes forestiers. De nombreuses études sont consacrées au bénévolat dans les domaines des soins hospitaliers, du travail social et de l'administration municipale, mais rares sont celles qui se sont penchées sur l'impact des bénévoles qui sont au service des terres publiques. Pour mieux connaitre cette main-d'œuvre, nous avons mené une étude transversale à l'aide d'enquêtes auprès de 176 bénévoles et de 19 coordonnateurs bénévoles (CB) pour le CSP dans le district de Santa Cruz d'août à octobre 2019. Le sondage portait sur les efforts des bénévoles dans la conservation des ressources, les services aux visiteurs et les opérations quotidiennes du parc. Nos résultats montrent que les bénévoles atteignent les objectifs de l'agence en facilitant les programmes d'interprétation, en fournissant des services aux visiteurs et en effectuant l'entretien des sentiers. Trois enjeux de gestion se sont dégagés de notre analyse, révélant les attributs qui rendent les programmes de bénévolat durables: 1) De multiples CB par unité de parc réduisent l'attrition des bénévoles; 2) Le recrutement de bénévoles sur la base de compétences professionnelles pertinentes maximise leur productivité; et 3) La réduction de l'attrition des $\mathrm{CB}$ préserve les connaissances institutionnelles et retient les bénévoles à long terme. En mettant en œuvre ces stratégies, les agences des terres publiques peuvent développer des programmes de bénévolat résilients capables de répondre aux besoins du parc et du personnel. 